known physical conditions, with the onset of maturity or even with migrations into different waters, and as such they have enormous value.

But, after studying the results obtained, certain investigators have doubted the validity of this method of ascertaining growth. It was noticed that in all species so investigated the calculated lengths for the first and succeeding winters became successively less and less as they were found from older and older fish, and other apparent discrepancies were pointed out by different observers. As a matter of fact, the above method gives only a first approximation to the actual lengths to which the fish grows at the end of each winter of life. It is based on the assumption that the lengths of the scale are themselves proportional to the length of the fish-a closer approximation (but still an approximation), for the calculation is given by taking the increments of growth of the scale as proportional to the increments of growth of the fish, starting from the point at which the scale first appears, which is in most cases an amount sufficiently appreciable to affect the calculations of the first two or three winter lengths considerably.

In Fig. 3 the average relations in the observed lengths of the scale and the corresponding fish, and in the observed lengths of the fish and the corresponding scales, are shown by the dots and crosses respectively.

A mathematical relation can be found by combining all the corresponding measures of scales and fish. This is known as a correlation coefficient, and in the case depicted was very high, viz. $r=0.95$. The points lie very nearly on straight lines, known as "regression lines," the mathematical equations to which are $\mathrm{L}=4 \cdot 8 \mathrm{~V}+3$ and $\mathrm{V}=0.19 \mathrm{~L}-0.36$. From the first of these equations the length of the fish can be calculated when the length of the scale is known from measurements.

The general form of this equation for any series of measurements of fish and their scales is $\mathrm{L}=a \mathrm{~V}+c$, the constant term $c$ corresponding to the length at which the scale begins to grow. In the case of North Sea herring $c$ is about $3 \mathrm{~cm}$.

As in practice only relative lengths of the winter rings are measured on the scale, the constant $a$ in the equation can be eliminated, and the calculated lengths to any previous winter $\left(L_{1}, L_{2}\right.$, etc.) derived from the equation put in the form

$$
\mathrm{L}_{1}=c+\frac{v_{1}}{\mathrm{~V}}(\mathrm{~L}-c), \text { etc. }
$$

The results obtained by the use of this formula

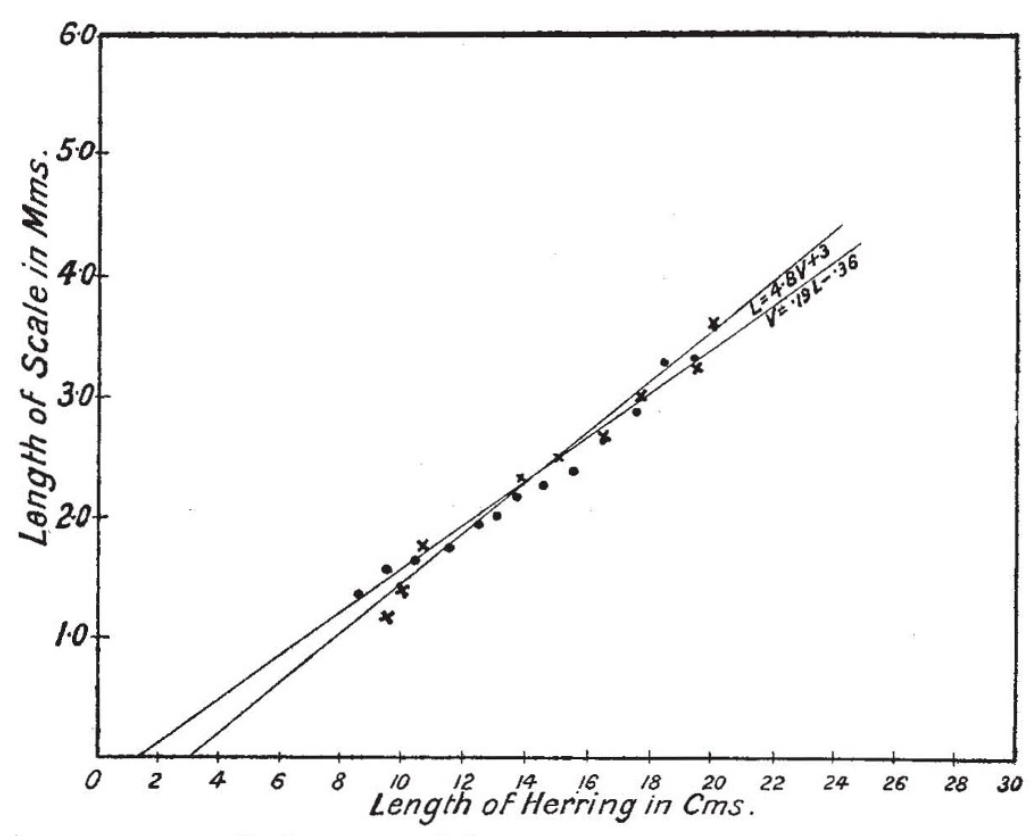

approximate more closely to values derived from observation than in the case of the original formula when $c$ is not taken into account, and the growth measures calculated in this way can therefore be assumed to be a closer approximation to the truth.

In all cases of age and growth determination individual records may be wrong, owing to one or other of many difficulties that may occur in deciphering the scale, but the latest work on the subject has shown that average values, both of age distribution in a sample and of amount of growth, are approximately correct.

\title{
The Structure of the Atom.
}

By C. G. Darwin.

\section{I.--Atomic Number.}

THE study of the interior structure of the atom was initiated about twenty-five years ago by J. J. Thomson's discovery of the electron. Electrons are particles of negative electricity of charge $4.77 \times 10^{-10}$ electrostatic units and mass $9.0 \times 10^{-28} \mathrm{gr}$., and they were shown to be conNo. 2654 , VOL. IO67 stituents of every type of matter. Some years previously Thomson had shown on theoretical grounds that any charged body should possess extra mass on account of its charge, and these two facts taken together suggested the possibility of an electrical theory of matter, whereby all mass should be electromagnetic in origin, and 
all the properties of matter should be reproduced by the interactions of electrons and positive charges, the latter at that time quite unknown. It is not possible to dwell here on the earlier atom models (such as those of Thomson or Ritz) which were devised on these lines. They had a certain measure of success in explaining some of the properties of matter; but we can now see that there was insufficient experimental knowledge at that time, and also that no theory could possibly work which was based on the old classical ideas of dynamics, as these are certainly inadequate to deal with atomic problems.

As electrons were known to be common to all matter, it was natural to ask how many were contained in each type of atom. The mass of an electron is about $\mathrm{r} / \mathrm{I} 84^{\circ}$ of that of a hydrogen atom, and therefore this atom cannot contain more than 1840 electrons. For other elements the corresponding upper limit is given by multiplying the atomic weight by 1840 . Thus in all cases a very wide field of choice is left. The attack on the problem was not possible until the development of $\mathrm{X}$-rays and radio-activity had reached a certain stage of advancement, for ordinary chemical and physioal methods are quite incapable of penetrating beyond the surface layers of the atom, whereas both X-rays and the radio-active particles are so powerful that they can go right through the atom, and from their behaviour in passing we can deduce a certain amount about its interior. With both the method consists in observing the phenomenon of scattering; that is to say, a narrow parallel beam is sent through a plate, and the amounts are found which are thrown off at various angles. Theory tells us how much a single electron should scatter, the number of atoms in the plate is known with some accuracy, and so we can count the number of electrons in each atom, if we assume that the scattering is due to them alone. When this method is applied with either $\mathrm{X}$-rays or $\beta$-particles (the latter are simply electrons moving at a high speed), certain theoretical complications make the results rather inaccurate, but in both cases the experiments clearly indicated that the number of electrons in the atom was of the same general magnitude as the atomic weight. This was found for several elements ranging in weight between carbon and gold. So our first upper limit to the number of electrons in the atom was vastly in excess, and no considerable fraction of the mass of an atom is contributed by its electrons.

The experiments with $\alpha$-particles were far more definite. An $\alpha$-particle is simply a helium atom, carrying a positive charge equal to that of two electrons, and moving at a very high speed. As the atomic weight of helium is 4 , it is seven thousand times as heavy as an electron. When an $\alpha$-particle passes an electron the attractive force sets the electron in motion, and the reaction of this force gives the $a$-particle a small deflection and reduces its velocity slightly. On account of the smallness of the effect of a single electron, great uniformity is obtained in the average, and the No. 2654 , VOL. IO6] number of electrons in an atom can be counted by observing either the scattering of the beam or else the rate at which the particles lose their velocity. Both give the same result, that the number of electrons in an atom is approximately half its atomic weight.

But the experiments on the scattering of $\alpha$-particles contained the germ of far more important information. For in the course of them it was observed that a certain small fraction of the $\alpha$-particles underwent large deflections. A few even were thrown right backwards. Now this fraction, though small in itself, was out of all proportion large compared with what could be given by the cumulative effect of a large number of collisions with electrons. Rutherford showed that the only reasonable hypothesis to account for this type of scattering was to suppose that the large deflections were produced in a single step. In this way he was led to put forward the nucleus theory of the atom, now universally accepted. According to this theory practically the whole mass of the atom is carried by a nucleus of very small dimensions (at most $10^{-12} \mathrm{~cm}$.) which has a charge of positive electricity equal to some multiple of the electronic charge. This nucleus is surrounded by a cloud of electrons of just such a number as to neutralise its charge. Each element has a different nuclear charge, and (to anticipate some results that we shall come to later) the value of this nuclear charge completely determines all the chemical characters of the element. Radioactive properties belong to the nucleus, as well as mass, while chemical and spectroscopic properties are attributed to the electrons of the cloud, and are only indirectly controlled by the nucleus because it determines the number and arrangement of these surrounding electrons. The dynamical structure of this planetary system was left unspecified, and remains to this day almost unknown.

Now consider the bearing of this theory on the question of scattering. The $\boldsymbol{\alpha}$-particle is itself the nucleus of a helium atom. In passing through matter most of the particles will not go very near any nucleus, and so will behave in the way we have already discussed. But the paths of a few will take them near some nucleus, and large repulsive forces will be developed between the two positive charges. Most atoms are much heavier than $\alpha$-particles, and so the latter will describe hyperbolas according to Newton's laws, and pass off in new directions. It is a simple matter to calculate the number of particles to be expected at any inclination to the original beam in terms of their initial velocity and the charge on the nucleus. The comparison with experiment, therefore, first furnishes a test as to whether the law of force has been taken correctly, and then provides a value for the nuclear charge. In both particulars the experiments fully bore out the prediction, and it was found that the nuclear charge (measured with the electronic charge as unit) was about half the atomic weight for the lighter elements, and rather less than half for the heavier. 
Table of Atomic Numbers of the Elements.

\begin{tabular}{|c|c|c|c|c|c|c|c|c|c|c|}
\hline 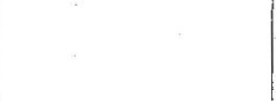 & $\begin{array}{l}\text { Hydrogen } \\
\text { 1. } \mathrm{H}, 1 \cdot 008 \\
\mathrm{x} \cdot 008\end{array}$ & & & & . & & & & & \\
\hline $\begin{array}{c}\text { Helium } \\
\text { 2. } \mathrm{He}, 4^{\circ} \mathrm{OO} \\
4\end{array}$ & 3. $\stackrel{\text { Lithium }}{\mathrm{Li}, 6 \cdot 94}$ & $\begin{array}{l}\text { Bergllium } \\
\text { 4. Be, } 9^{\circ} \mathrm{I}\end{array}$ & $\begin{array}{l}\text { Boron } \\
\text { 5. B, 10 } 9 \\
\text { 10, II }\end{array}$ & $\begin{array}{l}\text { Carbon } \\
\text { 6. }{ }_{12} 12 \cdot 00\end{array}$ & $\begin{array}{l}\text { Nitrogen } \\
\text { 7. } \mathrm{N}, 14 \cdot \mathrm{OI}\end{array}$ & $\begin{array}{l}\text { Oxygen } \\
\text { 8. } 0,16.00 \\
16\end{array}$ & 9. $\begin{array}{c}\text { Fluorine } \\
\mathrm{f}, \mathrm{I} 9 \\
19\end{array}$ & & & \\
\hline $\begin{array}{r}\mathrm{Neon} \\
\mathrm{Ne}, 2 \mathrm{O}^{\circ} 2 \\
2 \mathrm{O}, 22\end{array}$ & 11. $\stackrel{\text { Sodium }}{\mathrm{Na}, 23 \cdot 00}$ & $\begin{array}{l}\text { Magnesium } \\
\text { 12. } \mathrm{Mg}, 24^{\circ} 3^{2}\end{array}$ & 13. Al, $27^{\circ}$ & $\begin{array}{l}\text { Silicon } \\
\text { 14. } \mathrm{Si}, 28 \cdot 3 \\
28,29\end{array}$ & $\begin{array}{c}\text { Phosphoius } \\
\text { 15. P, } 31^{\circ} 04 \\
31^{\circ}\end{array}$ & $\begin{array}{l}\text { Sulphur } \\
\text { 16. } 3^{2} \cdot 3^{\circ} 06 \\
3^{2}\end{array}$ & $\begin{array}{l}\text { Chlorine } \\
\text { 17. } \mathrm{Cl}, 35 \cdot 46 \\
35,37\end{array}$ & & & \\
\hline 18. A, Argon $\begin{array}{r}39^{\circ}: 8 \\
36,40\end{array}$ & $\begin{array}{l}\text { Potassium } \\
\text { 19. } \mathrm{K}, 39^{\circ} \mathrm{I} \\
\text { 29. Copper } \\
\mathrm{Cu}, 63.57\end{array}$ & $\begin{array}{l}\text { 20. } \begin{array}{l}\text { Calcium } \\
\mathrm{Ca}, 40 \cdot 07\end{array} \\
\text { 30. } \mathrm{Zn}, 65 \cdot 37\end{array}$ & $\begin{array}{l}\text { Scandium } \\
\text { 21. Sc, } 44^{\circ} \mathrm{I} \\
\text { 31. Gallium } \mathrm{Ga}, 69^{\circ} 9\end{array}$ & $\begin{array}{l}\text { Titanium } \\
\text { 22. ' } \mathrm{l} \mathrm{i}, \mathbf{4}^{8} \cdot \mathrm{I} \\
\text { Germanium } \\
\text { 32. } \mathrm{Ge}, 72 \cdot 5\end{array}$ & $\begin{array}{l}\text { Vanadium } \\
\text { 23. V, 51.06 } \\
\text { Arsenic } \\
\text { 33. As, 74.96 } \\
75\end{array}$ & $\begin{array}{l}\text { Chromium } \\
\text { 24. Cr, } 5^{\circ} \circ \\
\text { Selenium } \\
\text { 34. Se, } 79^{\circ 2}\end{array}$ & $\begin{array}{c}\text { Manganese } \\
\text { 25. Mn, 54.93 } \\
\text { Bromine } \\
\text { 35. Br, 79.92 } \\
79,8 \mathbf{I}^{\circ}\end{array}$ & 26. $\mathrm{Fe}, 55 \cdot 85$ & 27. $\begin{array}{l}\text { Cobalt } \\
\text { Co, } 5^{8} \cdot 97\end{array}$ & 28. $\begin{array}{l}\text { Nickel } \\
\mathrm{Ni}, 5^{8} \cdot 68\end{array}$ \\
\hline $\begin{array}{l}\text { Krypton } \\
\text { 36. Kr, 82:92 } \\
78,80,82,83,84,86\end{array}$ & $\begin{array}{l}\text { Rubidium } \\
\text { 37. } \mathrm{Rb}, 85.45 \\
\text { Silver } \\
\text { 47. } \mathrm{Ag}, 107.88\end{array}$ & $\begin{array}{l}\text { Strontium } \\
\text { 38. Sr, } 87 \cdot 83 \\
\text { Cadmium } \\
\text { 48. Cd, II } 2_{4}\end{array}$ & $\begin{array}{l}\text { Ye. Ytrium } \\
Y, 88 \cdot 7 \\
\text { 49. Indium } \\
\text { In, } 114.8\end{array}$ & $\begin{array}{l}\text { Zirconium } \\
\text { 40. } \mathrm{Zr}, 90 \cdot 6 \\
\text { Tin } \\
\text { 50. } \mathrm{Sn}, 118.7\end{array}$ & $\begin{array}{l}\text { Niobium } \\
\text { 41. } \mathrm{N} b, 93.5 \\
\text { Antimony } \\
\text { 51. Sb, } \mathbf{1 2 0}^{\circ} \mathbf{2}\end{array}$ & $\begin{array}{l}\text { Molybdenum } \\
\text { 42. Mo, } 96.0 \\
\text { Tellurium } \\
\text { 52. Te, } 127.5\end{array}$ & $\begin{array}{l}\text { 43. }- \\
\text { 53. Iodine } \\
\text { 5, } 12692\end{array}$ & $\begin{array}{c}\text { Ruthenium } \\
\text { 44. Ru, } 101.7\end{array}$ & 45. Rh, IO2.9 & $\begin{array}{l}\text { Palladium } \\
\text { 46. Pd, 106.7 }\end{array}$ \\
\hline $\begin{array}{l}\text { Xenon } \\
\text { 54. Xe, I } 30^{\circ} 2 \\
\text { I } 28,130-1-3-5\end{array}$ & $\begin{array}{l}\text { 55. Cs, } \mathrm{I} 32 \cdot 8 \mathrm{I} \\
\text { Samarium } \\
\text { 62. Sa, I } 150 \cdot 4 \\
\text { Thulium } \\
\text { 69. Tu, I68.5 } \\
\text { Gold } \\
\text { 79. Au, } 197 \cdot 2\end{array}$ & $\begin{array}{l}\text { Barium } \\
\text { 56. Ba, } 137 \cdot 37 \\
\text { Europium } \\
\text { 63. Eu, 152.0 } \\
\text { Ytterbium } \\
\text { 70. Yh, I73.5 } \\
\text { Mercury } \\
\text { 80. Hg, 200.6 } \\
\text { 197-204 }\end{array}$ & $\begin{array}{c}\text { Lanthanum } \\
\text { 57. La, } 139^{\circ} \circ \\
\text { Gadolinium } \\
\text { 64. Gd, I57 } 3 \\
\text { Lutecium } \\
\text { 71. Lu, } 175 \\
\text { Thallium } \\
\text { 81. Tl, 204. } \\
\text { IV. }\end{array}$ & $\begin{array}{l}\text { 58. Cerium } \\
\text { Ce, } 140 \cdot 25 \\
\text { Terbium } \\
\text { 65. Th, 159.2 } \\
\text { Keltium } \\
\text { 72. Kt } \\
\text { 82. Pb, 207.2 } \\
\text { XI. }\end{array}$ & $\begin{array}{c}\text { Praseodymium } \\
\text { 59. Pr, 140.6 } \\
\text { Dysprosium } \\
\text { 66. Ds, 162.5 } \\
\text { Tantalum } \\
\text { 73. Ta, 181.5 } \\
\text { Bismuth } \\
\text { 83. W, 208.0 } \\
\text { V. }\end{array}$ & $\begin{array}{l}\text { Nend, mium } \\
\text { 60. Nd, 144.3 } \\
\text { Holmium } \\
\text { 67. Ho, } 163^{\circ} 5 \\
\text { Tungsten } \\
\text { 74. W, } 184^{\circ} \circ \\
\text { Polonium } \\
\text { 84. VIr. }\end{array}$ & $\begin{array}{l}\text { 61. } \\
\text { 68. Erbium } \\
\text { Er, 167\% } \\
\text { 75. }- \\
\text { 85. - }\end{array}$ & 76. Osmium & $\begin{array}{l}\text { Iridium } \\
\text { 77. Ir, I9.' I }\end{array}$ & $\begin{array}{l}\text { Platinum } \\
\text { 78. } \mathrm{Pt}, 195^{\circ} 2\end{array}$ \\
\hline $\begin{array}{l}\text { Emanation } \\
\text { III. }\end{array}$ & 87. - & $\begin{array}{l}\text { 88. Radium } \\
\text { Ra, } 226 \cdot 0 \\
\text { IV. }\end{array}$ & $\begin{array}{l}\text { Actinium } \\
\text { 89. Ac } \\
\text { II. }\end{array}$ & 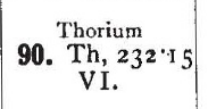 & 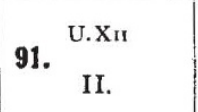 & $\begin{array}{l}\text { 92. Uranium } \\
\text { II. } 23^{8} \cdot 2\end{array}$ & & & & \\
\hline \multicolumn{11}{|c|}{ 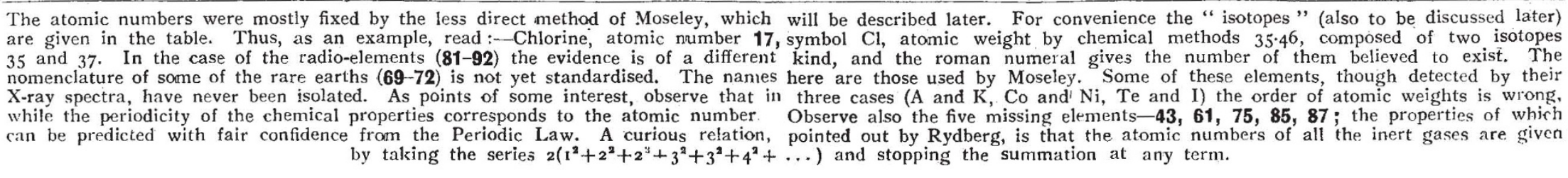 } \\
\hline
\end{tabular}


This method of determining the number of electrons in the atom is by far the most direct yet devised, as the interpretation of the experiments does not involve the rather difficult averaging necessary for the compound scattering produced by the electrons.

Now if we make a table of all the elements arranged in order of atomic weights, as is done by chemists for the study of the Periodic Law, and if we number them in this order, starting with hydrogen at $\mathrm{I}$, helium at 2 , and so on, as on p. 53 , it will be seen that the resulting numbers are always in the neighbourhood of half the atomic weight. The nuclear charge is by hypothesis some multiple of the electronic charge, and by experi- ment is about haif the atomic weight, and so we are almost forced to suppose that the ordinal number of an element in the table is the same as the number of electronic charges on its nucleus. We do not anticipate an exact correspondence throughout the table, because there may be (and in fact are) gaps in it which represent hitherto undiscovered elements. But apart from this we arrive at the conception of an atomic number for each element. The atomic number of an element is defined as the number of positive electronic charges carried by its nucleus, or, which is the same thing, as the number of electrons surrounding this nucleus.

(To be continued.)

\section{Obituary.}

Canon C. H. W. Johns.

BY the death of the Rev. C. H. W. Johns, $B$ Master of St. Catharine's College, Cambridge, and Canon of Norwich, Assyriology has lost another of its most prominent representatives in this country. It was almost exactly a year after the death of Prof. L. W. King that Canon Johns passed away. He had been noted as an Assyrian scholar for many years past; held the post of lecturer in Assyrian at his college of Queens', in the University of Cambridge, for fourteen years; and preceded Prof. King as Assyrian reader at King's College, London. These lectureships he vacated on his appointment as Master of St. Catharine's in Igog. The duties of the head of a college in no way interfered with the continued prosecution of his Assyrian studies, and to the last Dr. Johns was at work on the cuneiform inscriptions to which he had devoted a large part of his life. He was an excellent decipherer of the tablets, and had had much experience as a student of Ashurbanipal's library in the British Museum, to the officials of which, and especially to the late Prof. King, he was always persona grata and a valued colleague in science. His most notable publication is probably his "Assyrian Deeds and Documents," published in 1898 - a series of copies and translations of a large number of cuneiform legal and other records preserved in the British Museum. He also wrote on the famous legal code of Hammurabi, delivered the Schweich Lectures on the relations between the Laws of Babylonia and the Laws of the Hebrew peoples, and contributed articles on Mesopotamian law and history to various scientific journals and dictionaries, notably to the "Encyclopædia Biblica." His death is a great loss to the scientific study of Mesopotamian archæology.

H. R. HALL.

Prof. Adam Politzer, whose death has just been announced from Vienna, was recognised in all lands as the leading specialist of his time in diseases of the ear. He was born in Hungary on October I, I835, and, taking his medical degrees at the University of Vienna in 1859 , went NO. 2654 , VOL. IO6] abroad to study the anatomy and diseases of the ear, coming to London to work at the pathology of the ear under Mr. Joseph Toynbee, F.R.S. Returning to Vienna, he quickly established himself as the leading exponent of the newest learning concerning the organ of hearing and its defects, and his growing fame drew medical men to Vienna from all parts of the civilised world. The secret of his success was that he founded his methods of treatment on a first-hand knowledge of the structure, action, and pathology of all parts of the ear. He sought to give to the practice of the aural surgeon a foundation on fact, and not the least of his discoveries were made in the fields of normal anatomy.

The death of Sir Charles Lyall leaves a gap in the ranks of the older school of Orientalists, in which field he will be remembered rather than as an eminent Indian administrator. Sir Charles became a member of the Civil Service in the United Provinces of Agra and Oudh in 1867 , and, without much experience of district work, he was absorbed in the Provincial Secretariat, and then went to Simla and Calcutta. Much of his service was passed in Assam, of which province he became Chief Commissioner. Transferred to the Central Provinces, his training in administration failed to prepare him for the emergency of the great famine of 1897 , and he was removed to the India Office as Secretary of the Judicial and Public Department. Here he was able to resume his work on Indian languages, particularly Hindustani, and he showed his profound knowledge of Arabic by numerous translations of its poetic literature, which he discussed in successive editions of the "Encyclopædia Britannica." Sir Charles Lyall was a tower of strength to the Royal Asiatic Society, of which he was vice-president, working with Orientalists like James Kennedy and Vincent A. Smith, both of whom recently died. His services to literature were rewarded by several honorary degrees, and by the coveted distinction of fellowship of the British Academy. 